Check for updates

Cite this: J. Mater. Chem. A, 2018, 6 , 5208

Received 21st December 2017 Accepted 30th January 2018

DOI: 10.1039/c7ta11142h

rsc.li/materials-a

\section{Effects of ammonolysis and of sol-gel titanium oxide nitride coating on carbon fibres for use in flexible supercapacitors $\uparrow$}

\author{
Junxian Zhang, ${ }^{\text {ab }}$ Andrew L. Hector, (D) *a Samantha Soulé, ${ }^{a}$ Qinghua Zhang (D) *b \\ and Xin Zhao ${ }^{\mathrm{b}}$
}

\begin{abstract}
Smooth titanium oxide nitride coatings have been deposited on carbon fibres using a non-oxide sol-gel method based on self-condensation of titanium alkylamide species. Both the coating and a nitridation of the fibres resulting from the coating process increase the capacitance of the fibres measured in aqueous acid conditions, with significant redox capacitance contributions. When flexible symmetric capacitors were made from the coated fibres and an acid gel electrolyte they provided competitive energy and power densities. Their capacitance was retained very effectively on bending up to $180^{\circ}$
\end{abstract}

\section{Introduction}

Electrical charge storage in batteries and capacitors typically involves devices that are rigid in shape and cannot be incorporated into flexible objects without accommodating a bulky component. Fibre-based supercapacitors with flexible gel electrolytes are a promising way to integrate charge storage into items such as clothing without compromising on design. ${ }^{1,2}$ Carbon fibres have the advantages that they are relatively inexpensive, can maintain electronic conductivity over long distances and can be woven directly into flexible sheets.

In order to increase the charge storage capacity of flexible supercapacitors there are two key options, to increase the surface area of the carbon in order to maximise double layer capacitance or to incorporate redox functionalities. Polymers such as polyaniline can be incorporated onto fibre surfaces to provide this functionality. ${ }^{3}$ Various composites of redox-active metal oxides with carbon particles, tubes, fibres, sheets or 3dimensional structures have also been tested in flexible supercapacitors. ${ }^{4}$ Oxides used include $\mathrm{TiO}_{2},{ }^{5,6} \mathrm{~V}_{2} \mathrm{O}_{5},{ }^{7} \mathrm{WO}_{3},{ }^{8} \mathrm{Mn}_{2} \mathrm{O}_{3},{ }^{9}$ $\mathrm{MnO}_{2},{ }^{10-13} \mathrm{RuO}_{2},{ }^{14} \mathrm{Co}_{3} \mathrm{O}_{4},{ }^{15} \mathrm{NiO}^{16}$ and $\mathrm{CuO},{ }^{17}$ most of which have relatively low electronic conductivities.

Metal nitrides including TiN, ${ }^{18-28} \mathrm{VN},{ }^{29-39} \mathrm{TiVN}^{, 0}{ }^{40} \mathrm{NbN},{ }^{41,42}$ $\mathrm{Nb}_{4} \mathrm{~N}_{5},{ }^{43,44} \mathrm{CrN},{ }^{45} \mathrm{Mn}_{3} \mathrm{~N}_{2},{ }^{46} \mathrm{MoN},{ }^{47} \mathrm{Mo}_{2} \mathrm{~N},{ }^{48-52} \mathrm{Fe}_{2} \mathrm{~N},{ }^{53,54} \mathrm{RuN}^{55}$ and $\mathrm{WN}^{56}$ and $\mathrm{GaN}^{57}$ are increasingly studied for supercapacitor applications, with higher conductivities than the respective

${ }^{a}$ Chemistry, University of Southampton, Highfield, Southampton SO17 1BJ, UK. E-mail: A.L.Hector@soton.ac.uk

${ }^{b}$ State Key Laboratory for Modification of Chemical Fibers and Polymer Materials, College of Materials Science \& Engineering, Donghua University, Shanghai 201620, China.E-mail: qhzhang@dhu.edu.cn

$\dagger$ Electronic supplementary information (ESI) available: Including raw data. See DOI: $10.1039 / \mathrm{c} 7 \mathrm{ta} 11142 \mathrm{~h}$ oxides a key driver. In VN the capacity has been found to increase over initial cycles with surface oxide formation and high capacity has been attributed to this surface oxide. ${ }^{29}$ In TiN this is more complex, with some authors noting a decrease in capacitance ${ }^{18}$ but others noting "surface activation". ${ }^{20}$ Electrochemical oxidation prior to assembly of devices can enhance capacitance significantly. ${ }^{23}$ The performance of the native oxide surface on TiN has been linked to its nitrogen content, with a nitrogen-rich material achieving more capacity during cycling due to nitrogen doping of the surface oxide that enhances its conductivity. ${ }^{21}$ Titanium oxynitride nanostructures have also shown good supercapacitor performance. ${ }^{58}$

Non-oxide sol-gel methods can be used to produce a range of morphologies including metal nitride powders, films and porous structures. ${ }^{59-63}$ We recently showed that sols based on $\mathrm{Ti}\left(\mathrm{NMe}_{2}\right)_{4}$ and ${ }^{n} \mathrm{PrNH}_{2}$ could be used to coat nanocrystalline $\mathrm{LiFePO}_{4}$ powders providing an effective conductive surface when the powders were incorporated into lithium battery cathodes ${ }^{64}$ Herein we use an adaptation of that process to coat carbon fibres with the aim of exploiting a redox functionality in the coatings to provide increased capacitance.

\section{Experimental}

Tetrakisdimethylamido titanium $\left(\mathrm{Ti}\left(\mathrm{NMe}_{2}\right)_{4} ;\right.$ Epichem) was distilled in vacuo before use. n-Propylamine (Aldrich) was distilled from barium oxide. THF and hexane were purchased from Fisher and distilled from sodium/benzophenone ketyl ether. Carbon fibres were purchased from Zhongfu-Shenying Carbon Fiber Co., Ltd, and were immersed in concentrated sulfuric acid (AR, Pinghu Chemical Reagent Co., Ltd) at room temperature for $2 \mathrm{~h}$, then washed with deionized water several times and dried in the oven for $2 \mathrm{~h}$ (designated CF). Anhydrous ammonia (BOC) was dried by passing through a column of 
molecular sieves before use in ammonolysis reactions, and samples were loaded into furnace tubes that allowed air-free handling of samples prior to heating. Some carbon fibres were annealed under ammonia at $1000{ }^{\circ} \mathrm{C}$ for $6 \mathrm{~h}$ before use (designated $\mathrm{CF}-\mathrm{NH}_{3}$ ).

Sol preparation and fibre coating were carried out under nitrogen using Schlenk or glove box methods. $\mathrm{Ti}\left(\mathrm{NMe}_{2}\right)_{4}$ was dissolved in hexane (or THF) and ${ }^{n} \mathrm{PrNH}_{2}$ was added, the quantities of each component are shown in Table 1 . The solution gradually changed colour from yellow to red-orange. The hexane sols underwent some initial precipitation but this redissolved, as reported previously. ${ }^{62}$ After stirring at room temperature overnight the sols were used to coat carbon fibres by dipping into the sol and allowing the solvent to evaporate in the glove box. After coating with the titanium amide-based gel, the carbon fibres were heated under a flow of $\mathrm{NH}_{3}$ at $2.5{ }^{\circ} \mathrm{C} \min ^{-1}$ to $800{ }^{\circ} \mathrm{C}$ and maintained for $6 \mathrm{~h}$ before cooling. The prepared samples with different sol concentrations were designated as CF-TiN- $x(x=1,2,3,4,5$ depending on concentration, Table 1).

X-ray diffraction (XRD) patterns were obtained from fibres in transmission mode using a Rigaku Smartlab $(0.7 \mathrm{~mm}$ silica capillaries) or from powders using a Bruker D2 Phaser, both with $\mathrm{Cu}-\mathrm{K}_{\alpha}$ radiation. Phase matching used Rigaku PDXL2 and Rietveld refinements used the WPPF routine in PDXL2 with structure models from ICSD. ${ }^{65}$ Scanning electron microscopy (SEM) used a Philips XL30-ESEM or a Jeol JSM-6500F. Energy dispersive Xray analysis was carried out on the XL30 with a Thermofisher Ultradry detector and Noran System 7 processing. Thermogravimetric analysis (TGA) was carried out with a Netzsch TG209 F1 Libra, with a flowing $\mathrm{O}_{2} / \mathrm{Ar}$ mixture $\left(30 \mathrm{~cm}^{3} \mathrm{~min}^{-1 / 20}\right.$ $\mathrm{cm}^{3} \mathrm{~min}^{-1}$ ) and a heating rate of $5{ }^{\circ} \mathrm{C} \mathrm{min}^{-1}$. X-ray photoelectron spectroscopy (XPS) used a ThermoFisher Theta Probe spectrometer with focused, monochromatic $\mathrm{Al} \mathrm{K}_{\alpha}$ radiation (analysis chamber pressure $<3 \times 10^{-9} \mathrm{~Pa} ; h \nu=1486.6 \mathrm{eV}$; spot size $400 \mu \mathrm{m}$; constant pass energy of $40 \mathrm{eV}$ ). Short acquisition time spectra were recorded at the beginning and at the end of each experiment to check that the samples did not suffer from degradation and/or charging during the measurements. The Casa XPS software package was used for data analysis. The binding energy scale was calibrated from the graphitic carbon at $284.6 \mathrm{eV}$. Core peaks were analysed using a nonlinear Shirleytype background. ${ }^{66}$ Peak positions and areas were optimized by a weighted least-squares fitting method using 70\% Gaussian and $30 \%$ Lorentzian line shapes. Quantification was performed based on Scofield's relative sensitivity factors. ${ }^{67}$ For each sample,

Table 1 Quantities of reagents used in the preparation of each sol used to prepare TiN-coated carbon fibres (CF-TiN-x)

\begin{tabular}{llllllr}
\hline & & $x=1$ & $x=2$ & $x=3$ & $x=4$ & $x=5$ \\
\hline \multirow{2}{*}{$\left(\mathrm{NMe}_{2}\right)_{4}$} & Volume $/ \mathrm{cm}^{3}$ & 0.43 & 0.64 & 0.85 & 1.27 & 1.49 \\
& Moles $/ \mathrm{mmol}$ & 1.80 & 2.69 & 3.59 & 5.39 & 6.27 \\
${ }^{n} \mathrm{PrNH}_{2}$ & Volume $/ \mathrm{cm}^{3}$ & 0.30 & 0.44 & 0.59 & 0.89 & 1.04 \\
& Moles $/ \mathrm{mmol}$ & 3.59 & 5.39 & 7.18 & 10.78 & 12.57 \\
Hexane or THF & Volume $/ \mathrm{cm}^{3}$ & 7.50 & 7.50 & 7.50 & 7.50 & 7.50
\end{tabular}

several XPS analyses were performed at different positions to ensure the results were statistically reliable.

Cyclic voltammetry (CV), galvanostatic charge-discharge curves, electrochemical impedance spectroscopy and cycling stability measurements were conducted using a Biologics SP150 potentiostat. The electrochemical measurements were carried out in a three electrode electrochemical cell containing $1.0 \mathrm{~mol}$ $\mathrm{dm}^{-3} \mathrm{H}_{2} \mathrm{SO}_{4}$ aqueous solution as the electrolyte, a platinum gauze counter electrode and $\mathrm{Hg} / \mathrm{HgSO}_{4}\left(0.1 \mathrm{~mol} \mathrm{dm}{ }^{-3} \mathrm{~K}_{2} \mathrm{SO}_{4}\right)$ as the reference electrode at room temperature.

The gel electrolyte fibre supercapacitors were fabricated by sandwiching two $\mathrm{CF}-\mathrm{NH}_{3}$ or $\mathrm{CF}-\mathrm{TiN}-1$ fibre electrodes with a polypropylene non-woven fabric (Shanghai Heqi Glassware Co., Ltd.) separator. Each electrode and the separator were dipped twice into a PVA/ $\mathrm{H}_{2} \mathrm{SO}_{4}$ gel electrolyte. The gel electrolyte was prepared by a modification of a literature ${ }^{68}$ method: $3 \mathrm{~g}$ polyvinyl alcohol (PVA, molecular weight $1750 \pm 50$, Sinopharm Chemical Reagent Co., Ltd) and $4.5 \mathrm{~g}$ concentrated $\mathrm{H}_{2} \mathrm{SO}_{4}$ were mixed with $30 \mathrm{~cm}^{3}$ deionized water. The mixture was heated at $85{ }^{\circ} \mathrm{C}$ for $4 \mathrm{~h}$ and then allowed to cool to room temperature before use.

\section{Results and discussion}

Carbon fibres were coated with titanium oxynitride using a solgel approach that we have previously applied to make a number of titanium nitride morphologies. ${ }^{\mathbf{6 0 , 6 2 - 6 4}}$ A similar approach was employed by Yin et al. to coat graphite fibres with $\mathrm{Ti}(\mathrm{C}, \mathrm{N})$ to increase their oxidation resistance. ${ }^{69}$ Our method relies on the self-condensation of primary amide ligands that result from transamination of $\left[\mathrm{Ti}\left(\mathrm{NMe}_{2}\right)_{4}\right]$ using $n$-propylamine. Initially sols were produced in THF, but when these were used in attempt to coat carbon fibres distinct blocks of material, rather than a coating, were formed (ESI, Fig. S1 $\dagger$ ). Switching the solvent to hexane, sols formed that were effective in coating the carbon fibres, presumably due to better wetting of the

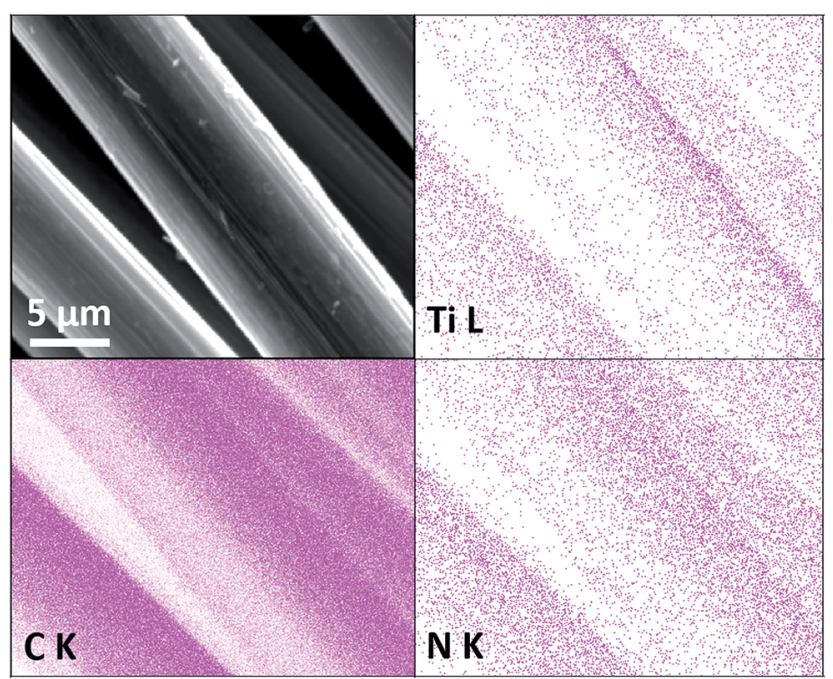

Fig. 1 SEM image and Ti, C and N EDX maps of carbon fibres coated with $\mathrm{Ti}(\mathrm{O}, \mathrm{N})(\mathrm{CF}-\mathrm{TiN}-4)$ and fired under ammonia at $800^{\circ} \mathrm{C}$. 


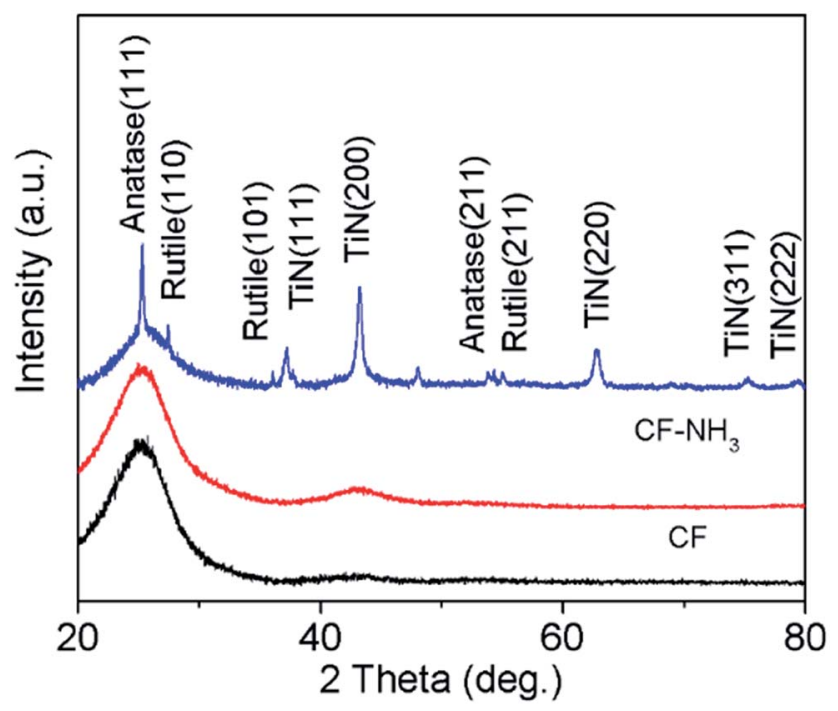

Fig. 2 XRD patterns of carbon fibres (CF), carbon fibres heated in ammonia at $800{ }^{\circ} \mathrm{C}\left(\mathrm{CF}-\mathrm{NH}_{3}\right)$ and carbon fibres coated with TiN (CFTiN-1).

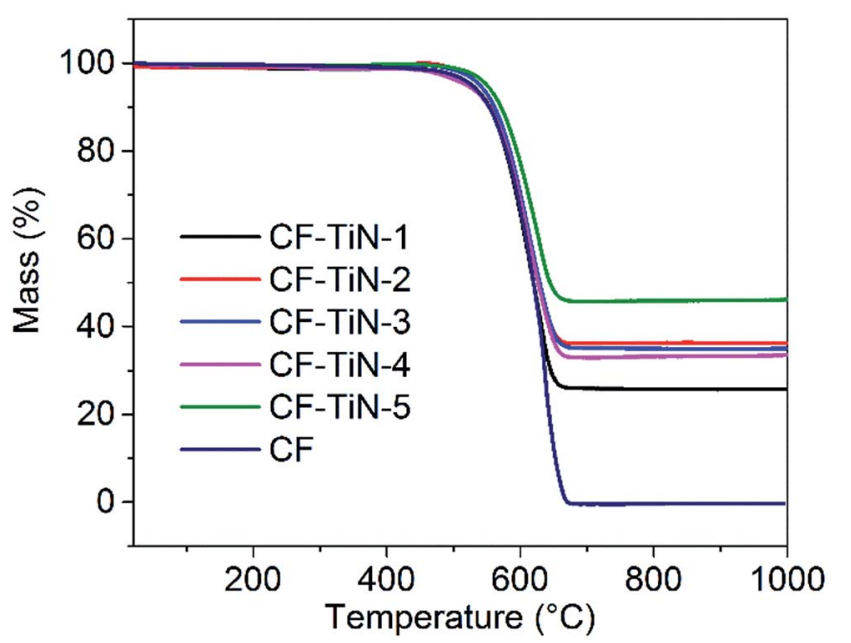

Fig. 3 TGA profiles of $\mathrm{Ti}(\mathrm{O}, \mathrm{N})$-coated carbon fibres heated under a $3: 2 \mathrm{O}_{2} /$ Ar mixture $\left(30 \mathrm{~cm}^{3} \mathrm{~min}^{-1} / 20 \mathrm{~cm}^{3} \mathrm{~min}^{-1}\right)$ at $5{ }^{\circ} \mathrm{C} \mathrm{min}^{-1}$. Residual masses were $0.04 \%$ (CF), 26.1\% (CF-TiN-1), 37.1\% (CF-TiN2), $35.3 \%(\mathrm{CF}-\mathrm{TiN}-3), 33.3 \%(\mathrm{CF}-\mathrm{TiN}-4)$ and $47.1 \%(\mathrm{CF}-\mathrm{TiN}-5)$.

hydrophobic carbon fibre surfaces by hexane compared with THF. Fig. 1 shows these coatings to be relatively smooth and continuous after firing in ammonia. Coatings were made with various sol concentrations (see Experimental) and the samples are then labelled as CF-TiN- $x$ where $x=1-5$.

In order to deconvolute any changes in the fibre composition or behaviour due to the coating process from the effects of the coating itself, comparisons were made between the carbon fibres, carbon fibres fired in ammonia and $\mathrm{Ti}(\mathrm{O}, \mathrm{N})$ coated carbon fibres fired in ammonia. The XRD patterns of the uncoated fibres, including those fired in ammonia, contained only broad features that can be attributed to the graphitic content of the carbon (Fig. 2). The coated fibres had TiN features superimposed onto the carbon pattern, but also always contained $\mathrm{TiO}_{2}$ in the rutile and anatase forms. Hence coatings are referred to as $\mathrm{Ti}(\mathrm{O}, \mathrm{N})$. The ammonia used in firing was carefully dried, so gels produced by removing the solvent from the sols in vacuo were also fired under the same conditions. The crystalline oxide phases were not observed in their XRD patterns. Hence, the oxide observed in the coatings is believed to derive from reactions of the oligomers within the sol with oxygen-containing groups on the carbon fibre surfaces. Sulfuric acid treatment of carbon fibres can be used to improve bonding to polymers in composite material production, and results in multiple oxygen-containing groups on the fibre surfaces. ${ }^{70}$ Rietveld fits to the XRD data showed TiN to be the major phase with smaller amounts of anatase and rutile (ESI, Fig. S2 and Table S1 $\dagger$ ). The TiN lattice parameter of 4.18-4.19 $\AA$ is typical of those reported in the literature. ${ }^{65}$

TGA showed a single mass loss step in all cases, with an onset temperature around $450{ }^{\circ} \mathrm{C}$ (Fig. 3). The uncoated carbon fibres combusted completely, but a white residue was left from the coated samples that was used to calculate how much titanium was in the samples. This residue was identified by XRD as rutile-type $\mathrm{TiO}_{2}$ (ESI, Fig. S3†), confirming that the TiN component had also been completely oxidised. Combining the Rietveld derived phase fractions (Table S1 $\dagger$ ) and the carbon contents from the TGA (Fig. 3) the overall compositions of the fibres can be calculated (Table 2).

The XPS analysis of the pristine carbon fibres evidences nitrogen $(400.7 \mathrm{eV})$ in low concentration at the surface $(2.5 \mathrm{at} \%)$ that can correspond to both pyrrolic $\mathrm{N}\left(\mathrm{H}-\mathrm{N}-(\mathrm{C})_{2}\right)$ and tertiary $\mathrm{N}$ $\left(\mathrm{N}-(\mathrm{C})_{3}-\right)$ (Fig. 4). After ammonia treatment the number of pyrrolic and tertiary $\mathrm{N}$ groups increases at the surface and a further environment at $398.1 \mathrm{eV}$ is observed on the $\mathrm{N} 1$ s core peak (ESI, Table $\mathrm{S} 2 \dagger$ ). That new environment is associated with pyridinic $\mathrm{N}(\mathrm{C}=\mathrm{N}-\mathrm{C}) .^{71,72}$ After coating, the XPS analysis shows a Ti $2 p$ signal with two different environments (Fig. 5). The broad $\mathrm{Ti} 2 \mathrm{p}_{3 / 2-1 / 2}$ doublet at $457.5-463.0 \mathrm{eV}$ is assigned to titanium oxynitride $\mathrm{TiO}_{x} \mathrm{~N}_{y}$ in agreement with the additional $\mathrm{N} 1 \mathrm{~s}$

Table 2 Calculated compositions of Ti(O,N)-coated carbon fibres fired at $800^{\circ} \mathrm{C}$ based on Rietveld phase fractions and TGA data

\begin{tabular}{|c|c|c|c|c|}
\hline & $\mathrm{C} / \mathrm{wt} \%$ & TiN (osbornite)/wt\% & $\mathrm{TiO}_{2}$ (rutile)/wt $\%$ & $\mathrm{TiO}_{2}$ (anatase)/wt $\%$ \\
\hline CF-TiN-1 & 78.3 & 14.8 & 4.0 & 2.9 \\
\hline CF-TiN-2 & 70.4 & 24.9 & 2.6 & 2.1 \\
\hline CF-TiN-3 & 70.2 & 18.4 & 4.8 & 6.6 \\
\hline CF-TiN-4 & 72.6 & 19.6 & 5.2 & 2.6 \\
\hline CF-TiN-5 & 63.0 & 29.3 & 6.7 & 1.0 \\
\hline
\end{tabular}




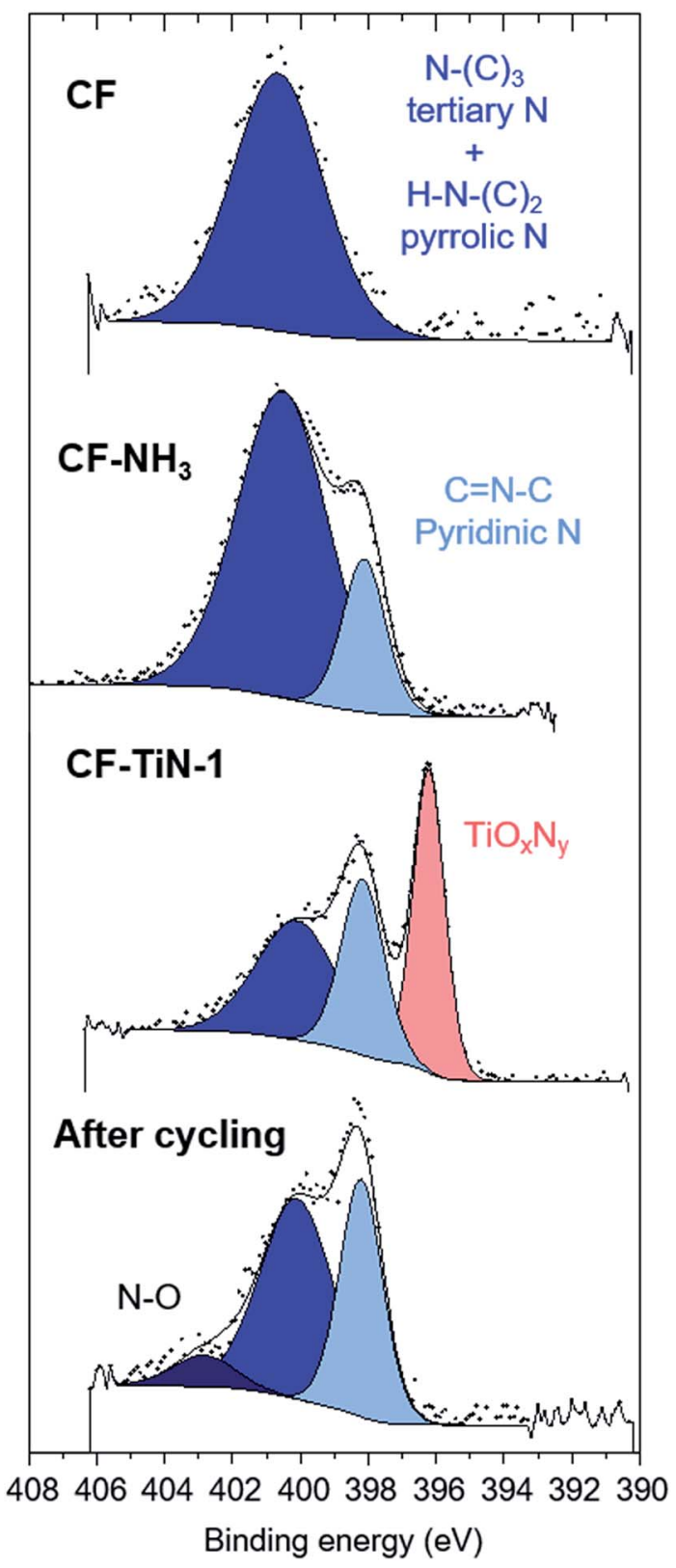

Fig. $4 \mathrm{~N}$ 1s XPS spectra of carbon fibre (CF), ammonia treated carbon fibre $\left(\mathrm{CF}-\mathrm{NH}_{3}\right)$, Ti(O,N)-coated carbon fibre $(\mathrm{CF}-\mathrm{TiN}-1)$ and postcycling TiN-coated carbon fibre samples.

component located at $396.2 \mathrm{eV} \cdot{ }^{23}$ The doublet at higher binding energy (459.1-464.8 eV) is characteristic of titanium dioxide. The Ti $2 \mathrm{p}_{3 / 2}$ peak of TiN occurs at $455 \mathrm{eV}$ and is not observed, showing that the TiN component of the coatings contains a surface oxide layer. C 1s and O 1s spectra are available (ESI, Fig. S4†).

Cyclic voltammograms of the carbon fibres were recorded in dilute sulfuric acid. The potential window was defined by recording a series of scans and limiting the potential range to avoid water oxidation or reduction, hence a window of -0.8 to $+0.2 \mathrm{~V} v s . \mathrm{Hg} / \mathrm{HgSO}_{4}$ was chosen. The CVs of the untreated fibres showed box-shaped features typical of double layer capacitance,

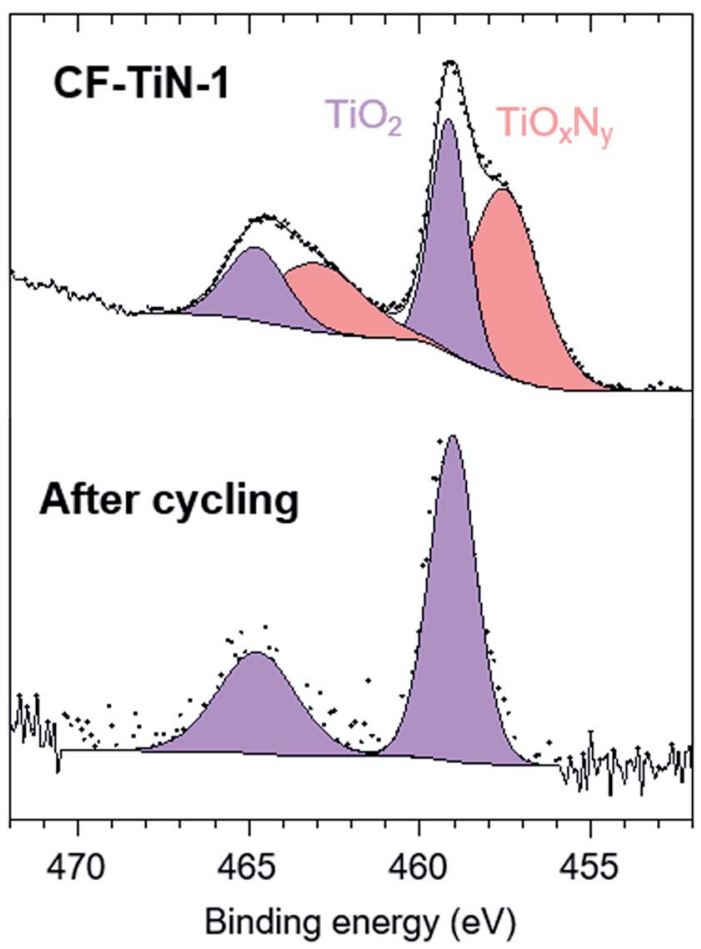

Fig. 5 Ti $2 p$ XPS spectra of TiN-coated carbon fibre (CF-TiN-1) and post-cycling $\mathrm{Ti}(\mathrm{O}, \mathrm{N})$-coated carbon fibre samples.

Fig. 6. Ammonolysis of the fibres before cell assembly resulted in a large increase in the currents observed in the CVs, retaining the same basic shape. The $\operatorname{Ti}(\mathrm{O}, \mathrm{N})$-coated fibre CVs showed redox features at $-0.56 \mathrm{~V}$ (oxidation) and $-0.75 \mathrm{~V}$ (reduction) superimposed onto the nitride fibre shape. These provided a $54 \%$ increase in the capacitance at a slow scan rate of $1 \mathrm{mV} \mathrm{s}^{-1}$ but much smaller increases at 10 or $300 \mathrm{mV} \mathrm{s}^{-1}$ (Table 3; CVs at further scan rates are provided in ESI, Fig. $\mathrm{S} 4 \uparrow$ and the method used to calculate capacitance is shown in ESI, Note $1 \dagger$ ). The extra capacitance was found to be particularly prominent below $\sim 50 \mathrm{mV} \mathrm{s}^{-1}$ scan rate, below which the capacitance ramped up steeply (ESI, Fig. S6†). This slower charge storage performance is typical of a redox process and likely indicates intercalation of protons into a surface oxynitride component of the $\operatorname{Ti}(\mathrm{O}, \mathrm{N})$ coating. The redox features observed for $\mathrm{TiO}_{2}$ coatings in similar conditions are expected to be at $\sim 0 \mathrm{~V} v s . \mathrm{Hg} / \mathrm{HgSO}_{4},{ }^{70}$ and with TiN the features are so broad that they tend not to be observed. $^{73}$

Similar results were obtained under galvanostatic cycling conditions. Redox features associated with the $\mathrm{Ti}(\mathrm{O}, \mathrm{N})$ coating were only observed at low potential at slower charge/discharge rates (Fig. 7), and the remainder of the profile closely resembled that of the ammonia-treated fibres (ESI, Fig. S7†). The ammonia treatment led to a significant increase in capacitance and the $\operatorname{Ti}(\mathrm{O}, \mathrm{N})$ coating increased the capacitance further at lower currents (Table 2). Comparison of the capacitances achieved with different thicknesses of $\operatorname{Ti}(\mathrm{O}, \mathrm{N})$ coating (ESI, Fig. S7 $\dagger$ ) showed that a thicker coating led to only small further increases, and that is why most of the work focused on the 


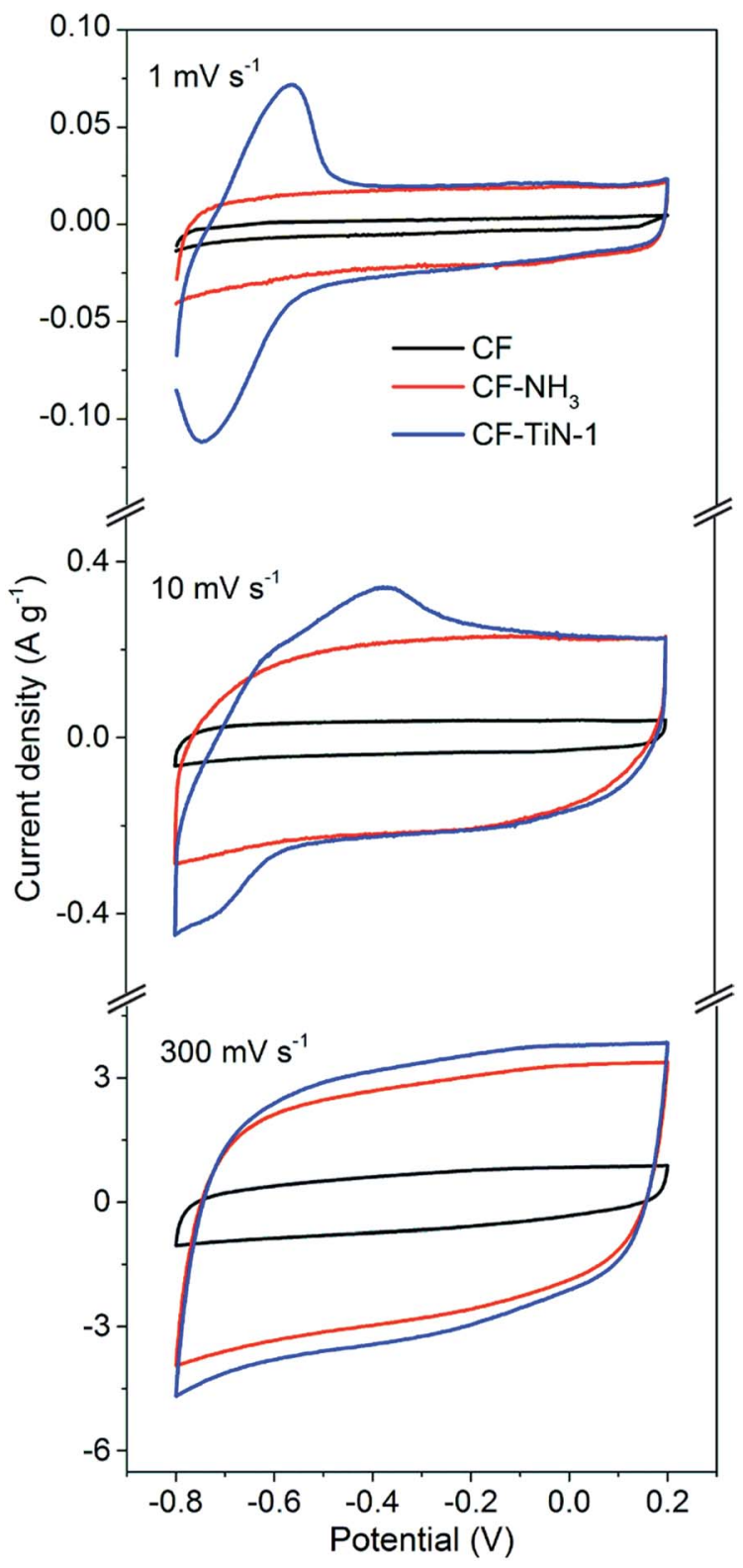

Fig. 6 Cyclic voltammograms $\left(1.0 \mathrm{~mol} \mathrm{dm}^{-3} \mathrm{H}_{2} \mathrm{SO}_{4}\right.$ aqueous solution, $\mathrm{Hg} / \mathrm{HgSO}_{4}\left(0.1 \mathrm{~mol} \mathrm{dm}{ }^{-3} \mathrm{~K}_{2} \mathrm{SO}_{4}\right)$, scan rates as labelled) of carbon fibres (CF), ammonia treated carbon fibres $\left(\mathrm{CF}-\mathrm{NH}_{3}\right)$ and $\mathrm{Ti}(\mathrm{O}, \mathrm{N})$ coated carbon fibres (CF-TiN-1).

Table 3 CV- and galvanostatically-measured capacitance values of untreated, nitride and TiN-coated carbon fibres in $1 \mathrm{~mol} \mathrm{dm}^{-3} \mathrm{H}_{2} \mathrm{SO}_{4}$

\begin{tabular}{llll}
\hline & & & \\
& $\mathrm{CF} / \mathrm{F} \mathrm{g}^{-1}$ & $\mathrm{CF}-\mathrm{NH}_{3} / \mathrm{F} \mathrm{g}^{-1}$ & $\begin{array}{l}\mathrm{CF}-\mathrm{TiN}-1 / \mathrm{F} \\
\mathrm{g}^{-1}\end{array}$ \\
\hline $1 \mathrm{mV} \mathrm{s}^{-1}$ & 3.3 & 19.4 & 29.9 \\
$10 \mathrm{mV} \mathrm{s}^{-1}$ & 4.7 & 26.9 & 30.3 \\
$300 \mathrm{mV} \mathrm{s}^{-1}$ & 2.6 & 11.7 & 13.2 \\
$0.1 \mathrm{~A} \mathrm{~g}^{-1}$ & 4.6 & 22.8 & 38.3 \\
$0.5 \mathrm{~A} \mathrm{~g}^{-1}$ & 3.0 & 16.5 & 20.0 \\
$1.0 \mathrm{~A} \mathrm{~g}^{-1}$ & 2.0 & 12.0 & 16.0
\end{tabular}
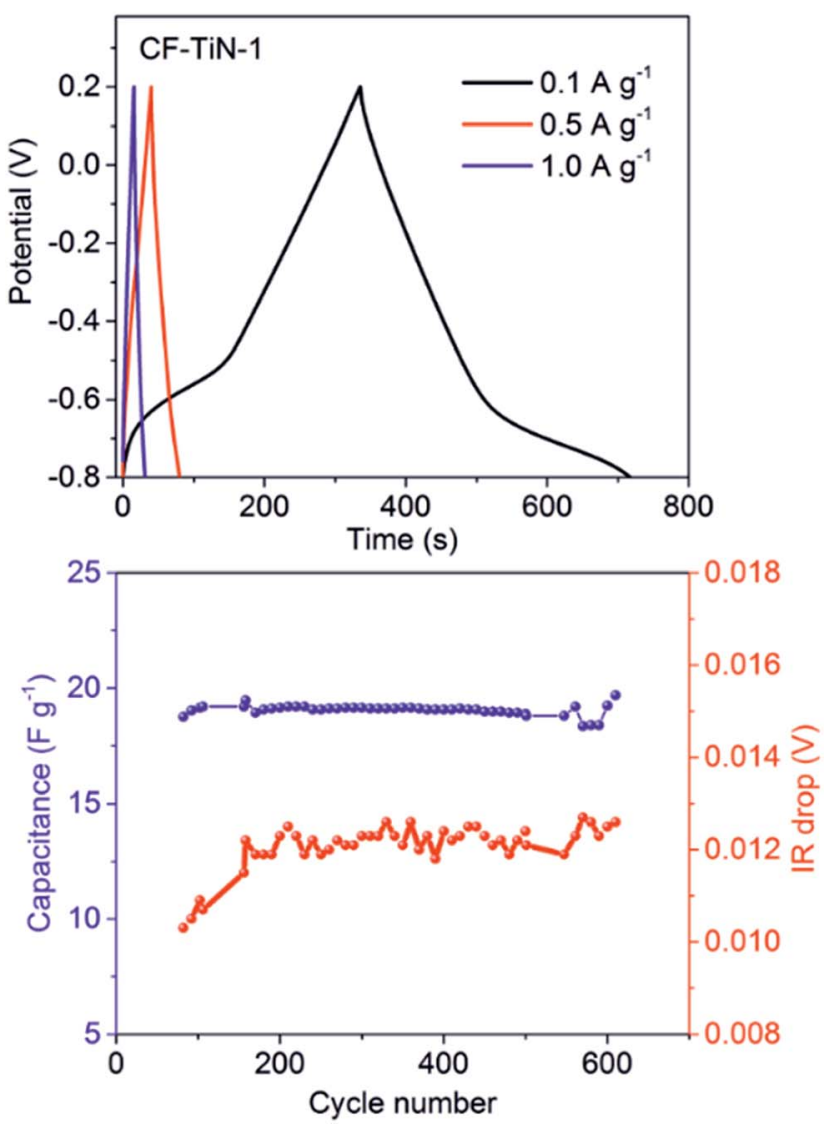

Fig. 7 Galvanostatic potential-time plots $\left(1.0 \mathrm{~mol} \mathrm{dm}^{-3} \mathrm{H}_{2} \mathrm{SO}_{4}\right.$ aqueous solution, $\mathrm{Hg} / \mathrm{HgSO}_{4}\left(0.1 \mathrm{~mol} \mathrm{dm}{ }^{-3} \mathrm{~K}_{2} \mathrm{SO}_{4}\right)$, scan rates as labelled) for $\mathrm{Ti}(\mathrm{O}, \mathrm{N})$-coated carbon fibres (CF-TiN-1; top) and variations in the capacitance and IR drop (measured as the voltage drop between the last charging and the first discharging data point) of the same fibres with cycle number at $0.5 \mathrm{~V} \mathrm{~s}^{-1}$ (bottom).

samples with the thinnest coatings. The capacitance was stable over 600 galvanostatic cycles, and low resistances were measured for these cells (Fig. 7).

After cycling, the components associated with $\mathrm{TiO}_{x} \mathrm{~N}_{y}$ on both $\mathrm{N}$ 1s and Ti 2p core peaks disappear (Fig. 4 and 5) and the at $\%$ of $\mathrm{TiO}_{2}$ decreases suggesting some loss of the coating and the surface layer being fully oxidised. The former is unsurprising, similar results are found with TiN electrodes ${ }^{23}$ and it should be remembered that XPS is only probing around 5$10 \mathrm{~nm}$ of the surface. The oxide is likely the redox active component and the nitride is present mainly to retain conductivity. Note that nitrogen is present even in this thin surface layer (Fig. 4), although the N 1s core peaks displays a new component at $402.9 \mathrm{eV}$ after cycling, indicating the formation of some oxidised nitrogen species. The surface oxidation could be responsible for the small increases in resistivity shown in Fig. 7, but overall the resistances remain low.

Resistance was also probed using electrochemical impedance spectroscopy. The spectra were mainly capacitive (Fig. 8), but showed small uncompensated solution resistances and charge transfer resistances. The latter were $7.6 \Omega$ for the carbon 


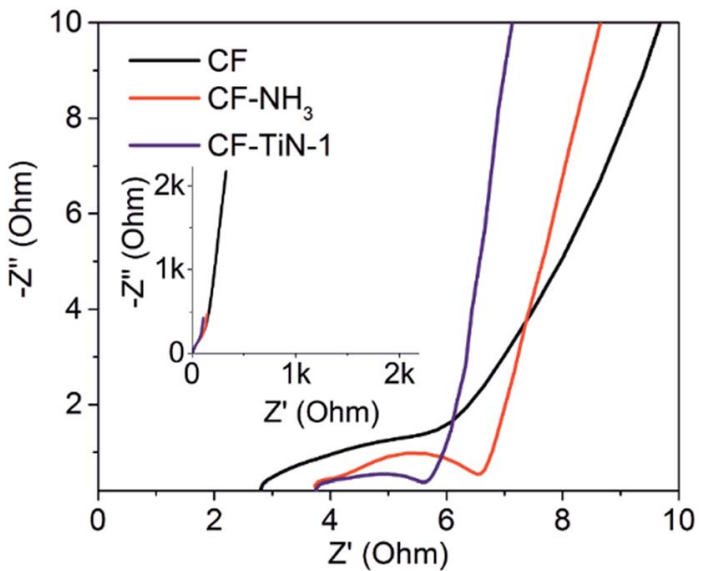

Fig. 8 Electrochemical impedance spectra $\left(1.0 \mathrm{~mol} \mathrm{dm}{ }^{-3} \mathrm{H}_{2} \mathrm{SO}_{4}\right.$ aqueous solution, $\mathrm{O} V \mathrm{vs}$. $\mathrm{Hg} / \mathrm{HgSO}_{4}\left(0.1 \mathrm{~mol} \mathrm{dm}{ }^{-3} \mathrm{~K}_{2} \mathrm{SO}_{4}\right)$, amplitude $10 \mathrm{mV}$, frequency range $10^{-2}$ to $10^{5} \mathrm{~Hz}$ ) of carbon fibres (CF), ammonia treated carbon fibres $\left(\mathrm{CF}-\mathrm{NH}_{3}\right)$ and $\mathrm{Ti}(\mathrm{O}, \mathrm{N})$-coated carbon fibres (CFTiN-1). Data were fitted using ZView to a series combination of a resistor (uncompensated solution resistance), a parallel resistor/ constant phase element (charge transfer resistance/interface capacitance), and a constant phase element (capacitance).

fibres, $6.4 \Omega$ for the ammonia treated carbon fibres and $6.1 \Omega$ for the $\operatorname{Ti}(\mathrm{O}, \mathrm{N})$-coated carbon fibres.

Symmetric gel electrolyte fibre supercapacitors were fabricated by sandwiching two $\mathrm{Ti}(\mathrm{O}, \mathrm{N})$-coated carbon fibre $(\mathrm{CF}-\mathrm{TiN}$ 1) electrodes with a polypropylene non-woven fabric. The electrode and separator were coated with a $\mathrm{PVA} / \mathrm{H}_{2} \mathrm{SO}_{4}$ gel electrolyte prior to assembly. Similar capacitors were also assembled and tested using the ammonia treated carbon fibres $\left(\mathrm{CF}-\mathrm{NH}_{3}\right)$.

Cyclic voltammograms of the symmetric cells over a $1 \mathrm{~V}$ potential range and at a moderate scan rate of $10 \mathrm{mV} \mathrm{s}^{-1}$ showed no redox features (Fig. 9) but the Ti(O,N)-coated fibres (CF-TiN-1) still showed a larger capacitance $\left(6.0 \mathrm{~F} \mathrm{~g}^{-1}\right.$ based on the mass of both electrodes) than the ammonia treated fibres $\left(\mathrm{CF}-\mathrm{NH}_{3} ; 3.8 \mathrm{~F} \mathrm{~g}^{-1}\right)$. The lack of redox features can be attributed to the electrodes in this symmetric environment not being exposed to the low potentials that were needed to activate the redox chemistry in the aqueous cells with a reference electrode. Thus the higher capacitance may be due to an increased surface area in the coated fibre samples. Similar results were found under galvanostatic cycling conditions, where symmetrical charge/discharge profiles were observed (Fig. 9). The $\mathrm{Ti}(\mathrm{O}, \mathrm{N})-$ coated fibres showed capacitances of $7.8 \mathrm{~F} \mathrm{~g}^{-1}$ at $0.1 \mathrm{~A} \mathrm{~g}^{-1}$, $6.9 \mathrm{~F} \mathrm{~g}^{-1}$ at $0.5 \mathrm{~A} \mathrm{~g}^{-1}$ and $6.6 \mathrm{~F} \mathrm{~g}^{-1}$ at $1.0 \mathrm{~A} \mathrm{~g}^{-1}$, compared with 3.4, 2.4 and $1.6 \mathrm{~F} \mathrm{~g}^{-1}$, respectively, for the ammonia-treated fibres $\left(\mathrm{CF}-\mathrm{NH}_{3}\right)$.

Flexibility during operation is a key potential advantage of supercapacitors constructed from fibres and with gel electrolytes. ${ }^{\mathbf{1 , 2 , 7 4}}$ Our symmetric supercapacitors were tested flat $\left(0^{\circ}\right)$, or bent through $90^{\circ}$ or $180^{\circ}$ with a $7 \mathrm{~mm}$ radius of curvature (geometry shown in ESI, Fig. S8 $\dagger$ ). Very little difference in behaviour was observed under $\mathrm{CV}$ or galvanostatic conditions (Fig. 10), showing that these devices are as flexible as they were intended to be. This good performance persisted over multiple
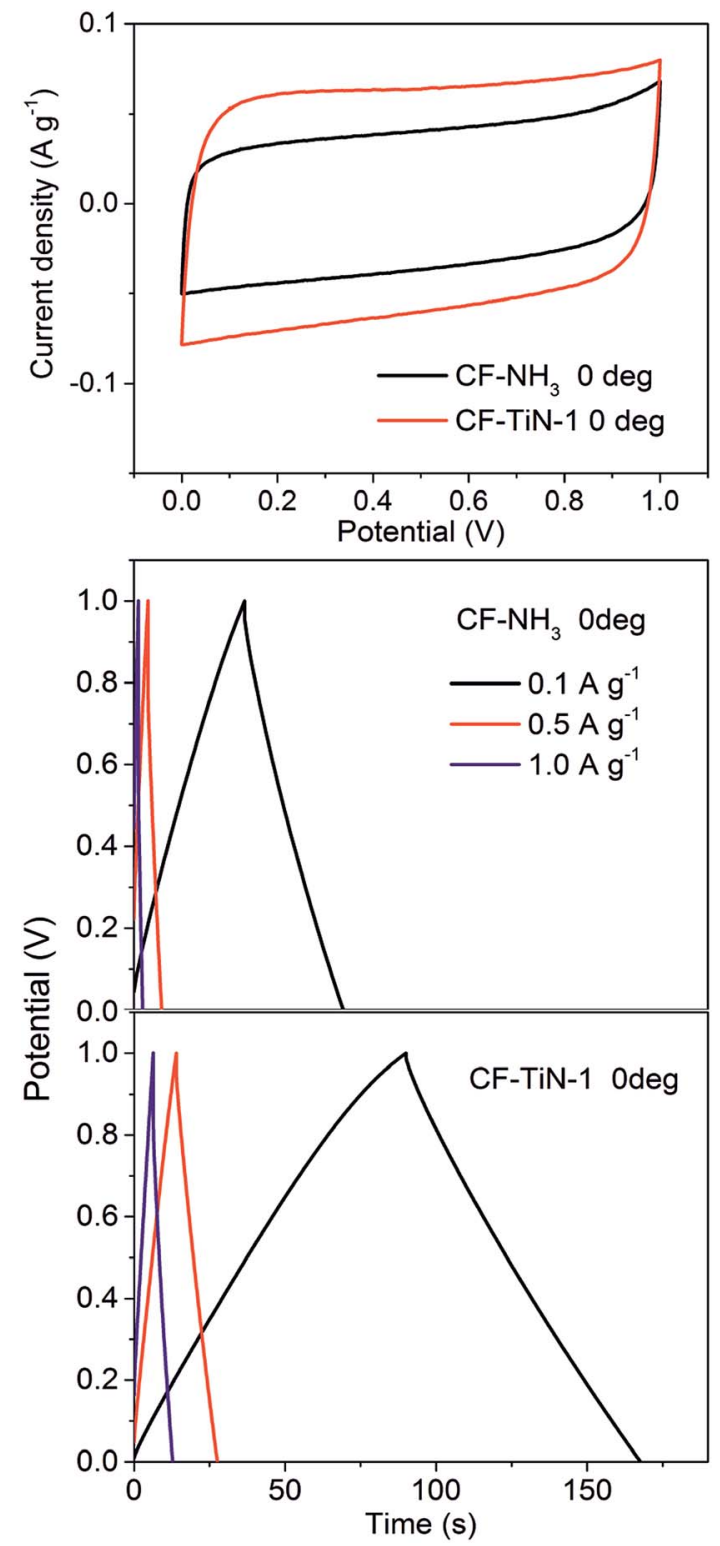

Fig. 9 Cyclic voltammograms (top) and galvanostatic potential-time plots (bottom) for symmetric supercapacitors assembled using ammonia-treated carbon fibre $\left(\mathrm{CF}-\mathrm{NH}_{3}\right)$ or $\mathrm{Ti}(\mathrm{O}, \mathrm{N})$-coated carbon fibre (CF-TiN-1) electrodes. The CV scan rate was $10 \mathrm{mV} \mathrm{s}^{-1}$ and galvanostatic current rates were as shown.

cycles, with a small drop off in capacitance over the first $\sim 2000$ cycles followed by quite steady capacitance over the next 6000 (Fig. 10). The retention in the capacitance over 8000 cycles was $77 \%$ at $0^{\circ}, 73 \%$ at $90^{\circ}$ and $83 \%$ at $180^{\circ}$. A video clip of a capacitor being flexed during galvanostatic cycling is available in the electronic ESI. $\uparrow$ Both ammonia-treated fibres and $\mathrm{Ti}(\mathrm{O}, \mathrm{N})$-coated fibres showed a drop-off in the CV-measured capacitance with increasing scan rate, but this was a little more pronounced in the $\mathrm{Ti}(\mathrm{O}, \mathrm{N})$-coated fibres (ESI, Fig. S9†). This suggests that redox activity was playing a role in their charge storage behaviour. The CVs also showed higher resistance at fast scan rates in the supercapacitors bent through 

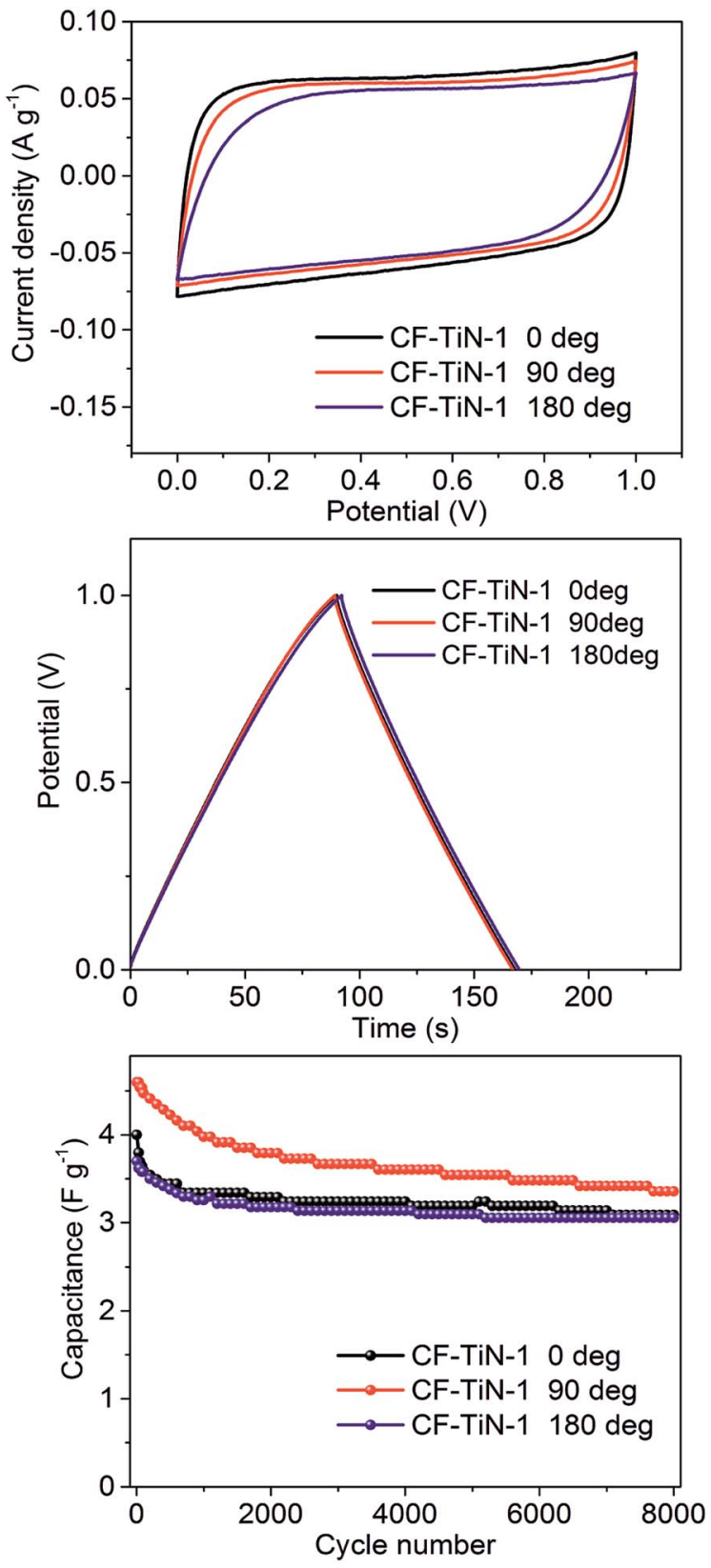

Fig. 10 Cyclic voltammograms $\left(10 \mathrm{mV} \mathrm{s}^{-1}\right.$; top), galvanostatic potential-time plots $\left(0.1 \mathrm{~A} \mathrm{~g}^{-1}\right.$, centre) and capacitance vs. cycle number calculated from the galvanostatic data $\left(0.5 \mathrm{~A} \mathrm{~g}^{-1}\right.$, bottom) of symmetric supercapacitors cycled flat $\left(0^{\circ}\right)$ or bent through a $90^{\circ}$ or $180^{\circ}$ angle.

larger angles (ESI, Fig. S9†), which may indicate that the contact between the layers is being interrupted to some extent by bending.

The specific capacitances achieved in this study compare favourably with other studies into flexible supercapacitors in terms of energy and power density, as shown in Fig. 11 (the calculation methods used for Fig. 11 are presented in ESI, Note $2 \dagger)$. As described above, this performance can be ascribed to the increases in charge storage density that come from the combination of nitridation of the fibres and the redox activity of the

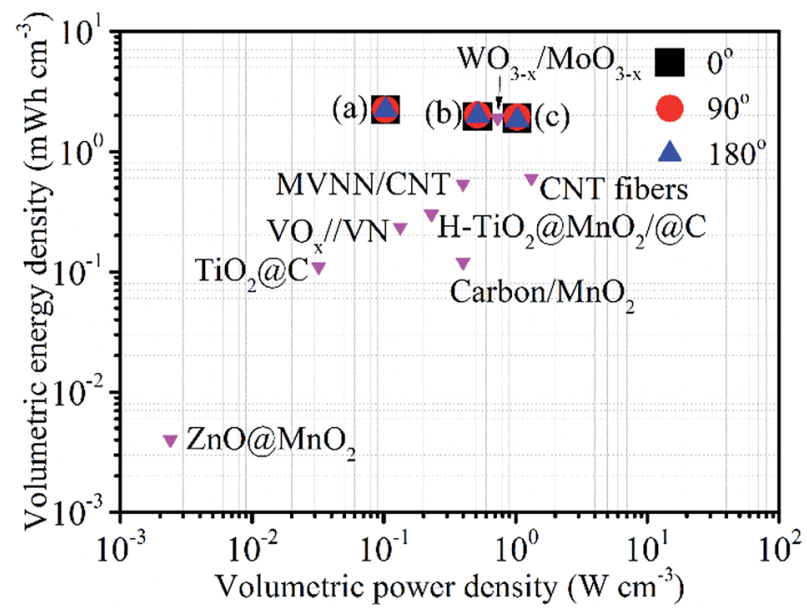

Fig. 11 Ragone plot comparing the volumetric energy and power densities of the solid flexible supercapacitor devices described in this study, measured under galvanostatic conditions at $0.1 \mathrm{~A} \mathrm{~g}^{-1}$ (a), $0.5 \mathrm{~A} \mathrm{~g}^{-1}$ (b) or $1 \mathrm{~A} \mathrm{~g}^{-1}$ (c) and at bending angles as indicated, with those of other flexible supercapacitors in the literature..$^{5,6,8,30,75-78}$

$\mathrm{Ti}(\mathrm{O}, \mathrm{N})$ surface coating. However, in the future it should be possible to take this approach further. For example, larger specific surface areas and better electron transport may be provided by 3dimensional carbon network structures, by weaving the fibres or using foam or reticulated carbon structures. Much of the redox activity of the $\operatorname{Ti}(\mathrm{O}, \mathrm{N})$ coatings is at low potential, so larger capacitances as well as higher voltages may be achievable in asymmetric capacitors by using such Ti(O,N)-coated carbon electrode systems in combination with an electrode that has redox activity at higher potential.

\section{Conclusions}

A non-oxide sol-gel method has been used to produce titanium oxide nitride coatings on carbon fibres. Smooth coatings were achieved by matching the solvent hydrophobicity to that of the fibre surfaces. The oxide component in the coatings appears to be due to interaction with surface oxygen-containing functionalities on the carbon fibres. The high temperature ammonia treatment required to crystallise the metal nitride also increases the nitrogen content of the fibres themselves. Both the surface nitridation and the $\operatorname{Ti}(\mathrm{O}, \mathrm{N})$ coatings contribute to increased capacitances in aqueous or gel acid environments. The main redox activity of the $\operatorname{Ti}(\mathrm{O}, \mathrm{N})$ component is at low potential, but even at fast scan rates, where no redox peaks were observed in cyclic voltammetry or galvanostatic experiments, this component increased the capacitance of the electrodes. The capacitors had low resistance and were stable over hundreds of cycles. Flexible capacitors made with an acidic gel electrolyte delivered competitive energy and power densities that were unaffected by bending the devices.

\section{Conflicts of interest}

There are no conflicts of interest to declare. 


\section{Acknowledgements}

JZ thanks the China Scholarship Council for funding for a visit to the UK. SS is supported by EPSRC under EP/N035437/1 and the Smartlab diffractometer was funded under EP/K00509X/1 and EP/K009877/1. XZ is supported by the DHU Distinguished Young Professor Program and the National Natural Science Foundation of China (51403036).

\section{Notes and references}

1 L. Liu, Z. Niu and J. Chen, Chem. Soc. Rev., 2016, 45, 43404363.

2 P. Yang and W. Mai, Nano Energy, 2014, 8, 274-290.

3 J. Jang, J. Bae, M. Choi and S. H. Yoon, Carbon, 2005, 43, 2730-2736.

4 M. Zhi, C. Xiang, J. Li, M. Li and N. Wu, Nanoscale, 2013, 5, 72-88.

5 H. Zheng, T. Zhai, M. Yu, S. Xie, C. Liang, W. Zhao, S. C. I. Wang, Z. Zhang and X. Lu, J. Mater. Chem. C, 2013, 1, 225-229.

6 X. Lu, M. Yu, G. Wang, T. Zhai, S. Xie, Y. Ling, Y. Tong and Y. Li, Adv. Mater., 2013, 25, 267-272.

7 S. D. Perera, B. Patel, N. Nijem, K. Roodenko, O. Seitz, J. P. Ferraris, Y. J. Chabal and K. J. Balkus Jr, Adv. Energy Mater., 2011, 3, 936-945.

8 X. Xiao, T. Ding, L. Yuan, Y. Shen, Q. Zhong, X. Zhang, Y. Cao, B. Hu, T. Zhai, L. Gong, J. Chen, Y. Tong, J. Zhou and Z. Wang, Adv. Energy Mater., 2012, 2, 1328-1332.

9 R. Zhou, C. Meng, F. Zhu, Q. Li, C. Liu, S. Fan and K. Jiang, Nanotechnology, 2010, 21, 345701.

10 J. G. Wang, Y. Yang, Z. H. Huang and F. Kang, Electrochim. Acta, 2011, 56, 9240-9247.

11 J. Zhang, X. Zhao, Z. Huang, T. Xu and Q. Zhang, Carbon, 2016, 107, 844-851.

12 Q. J. Le, T. Wang, D. N. H. Tran, F. Dong, Y. X. Zhang and D. Losic, J. Mater. Chem. A, 2017, 5, 10856-10865.

13 M. Li, M. Zhou, Z. Q. Wen and Y. X. Zhang, Journal of Energy Storage, 2017, 11, 242-248.

14 P. Chen, H. Chen, J. Qiu and C. Zhou, Nano Res., 2010, 3, 594-603.

15 L. Yang, S. Cheng, Y. Ding, X. Zhu, Z. L. Wang and M. Liu, Nano Lett., 2012, 12, 321-325.

$16 \mathrm{~J} . \mathrm{Li}, \mathrm{W}$. Zhao, F. Huang, A. Manivannan and N. Wu, Nanoscale, 2011, 3, 5103.

17 X. Zhang, W. Shi, J. Zhu, D. J. Kharistal, W. Zhao, B. S. Lalia, H. H. Hng and Q. Yan, ACS Nano, 2011, 5, 2013-2019.

18 D. Choi and P. N. Kumta, J. Electrochem. Soc., 2006, 153, A2298-A2303.

19 R. A. Janes, M. Aldissi and R. B. Kaner, Chem. Mater., 2003, 15, 4431-4435.

20 P. Yang, D. Chao, C. Zhu, X. Xia, Y. Zhang, X. Wang, P. Sun, B. K. Tay, Z. X. Shen, W. Mai and H. J. Fan, Adv. Sci., 2015, 3, 1500299.

21 A. Achour, R. L. Porto, M.-A. Soussou, M. Islam, M. Boujtita, K. A. Aissa, L. Le Brizoual, A. Djouadi and T. Brousse, J. Power Sources, 2015, 300, 525-532.
22 D. J. Kim, J. K. Kim, J. H. Lee, H. H. Cho, Y.-S. Bae and J. H. Kim, J. Mater. Chem. A, 2016, 4, 12497-12503.

23 B. M. Gray, A. L. Hector, M. Jura, J. R. Owen and J. Whittam, J. Mater. Chem. A, 2017, 5, 4550-4559.

24 K. Grigoras, J. Keskinen, L. Grönberg, E. Yli-Rantala, S. Laakso, H. Välimäki, P. Kauranen, J. Ahopelto and M. Prunnila, Nano Energy, 2016, 26, 340-345.

25 P. Lu, P. Ohlckers, L. Müller, S. Leopold, M. Hoffmann, K. Grigoras, J. Ahopelto, M. Prunnila and X. Chen, Electrochem. Commun., 2016, 70, 51-55.

26 Y. Xie and R. Gao, J. Alloys Compd., 2017, 725, 1-13.

27 Y. Haldorai, D. Arreaga-Salas, C. S. Rak, Y. S. Huh, Y. K. Han and W. Voit, Electrochim. Acta, 2016, 220, 465-474.

28 E. Kao, C. Yang, R. Warren, A. Kozinda and L. Lin, Sens. Actuators, A, 2016, 240, 160-166.

29 D. Choi, G. E. Blomgren and P. N. Kumta, Adv. Mater., 2006, 18, 1178-1182.

30 X. Lu, M. Yu, T. Zhai, G. Wang, S. Xie, T. Liu, C. Liang, Y. Tong and Y. Li, Nano Lett., 2013, 13, 2628-2633.

31 R. Lucio-Porto, S. Bouhtiyya, J. F. Pierson, A. Morel, F. Capon, P. Boulet and T. Brousse, Electrochim. Acta, 2014, 141, 203-211.

32 Z. Hou, K. Guo, H. Li and T. Zhai, CrystEngComm, 2016, 18, 3040-3047.

33 P. J. Hanumantha, M. K. Datta, K. Kadakia, C. Okoli, P. Patel and P. N. Kumta, Electrochim. Acta, 2016, 207, 37-47.

34 Y. Yang, K. Shen, Y. Liu, Y. Tan, X. Zhao, J. Wu, X. Niu and F. Ran, Nano-Micro Lett., 2017, 9, 1-15.

35 Y. Wu and F. Ran, J. Power Sources, 2017, 344, 1-10.

36 B. Wang, Z. Chen, G. Lu, T. Wang and Y. Ge, Mater. Res. Bull., 2016, 76, 37-40.

37 F. Ran, Z. Wang, Y. Yang, Z. Liu, L. Kong and L. Kang, Electrochim. Acta, 2017, 258, 405-413.

38 Y. Wang, M. Jiang, Y. Yang and F. Ran, Electrochim. Acta, 2016, 222, 1914-1921.

39 Y. Liu, L. Liu, L. Kong, L. Kang and F. Ran, Electrochim. Acta, 2016, 211, 469-477.

40 A. Achour, R. Lucio-Porto, M. Chaker, A. Arman, A. Ahmadpourian, M. A. Soussou, M. Boujtita, L. Le Brizoual, M. A. Djouadi and T. Brousse, Electrochem. Commun., 2017, 77, 40-43.

41 D. Choi and P. N. Kumta, J. Am. Ceram. Soc., 2011, 94, 23712378.

42 P. Wang, R. Wang, J. Lang, X. Zhang, Z. Chen and X. Yan, J. Mater. Chem. A, 2016, 4, 9760-9766.

43 H. Cui, G. Zhu, X. Liu, F. Liu, Y. Xie, C. Yang, T. Lin, H. Gu and F. Huang, Adv. Sci., 2015, 2, 1500126.

44 B. Gao, X. Xiao, J. Su, X. Zhang, X. Peng, J. Fu and P. K. Chu, Appl. Surf. Sci., 2016, 383, 57-63.

45 B. Wei, H. Liang, D. Zhang, Z. Wu, Z. Qi and Z. Wang, J. Mater. Chem. A, 2017, 5, 2844-2851.

46 S. I. U. Shah, A. L. Hector, X. Li and J. R. Owen, J. Mater. Chem. A, 2015, 3, 3612-3619.

47 Y. Xie and F. Tian, Mater. Sci. Eng., B, 2017, 215, 64-70.

48 C. Chen, D. Zhao and X. Wang, Mater. Chem. Phys., 2006, 97, 156-161. 
49 S. L. Roberson, D. Finello and R. F. Davis, J. Appl. Electrochem., 1999, 29, 75.

50 T.-C. Liu, W. G. Pell, B. E. Conway and S. L. Roberson, J. Electrochem. Soc., 1998, 145, 1882-1888.

51 S. I. U. Shah, A. L. Hector and J. R. Owen, J. Power Sources, 2014, 266, 456-463.

52 L. Chen, C. Liu and Z. Zhang, Electrochim. Acta, 2017, 245, 237-248.

53 L. Xu, L. Sun, J. Feng, L. Qi, I. Muhammad, J. Maher, X. Cheng and W. Song, RSC Adv., 2017, 7, 44619-44625.

54 A. Śliwak, A. Moyseowicz and G. Gryglewicz, J. Mater. Chem. A, 2017, 5, 5680-5684.

55 S. Bouhtiyya, R. Lucio Porto, B. Laïk, P. Boulet, F. Capon, J. P. Pereira-Ramos, T. Brousse and J. F. Pierson, Scr. Mater., 2013, 68, 659-662.

56 A.-R. Ko, S.-B. Han, Y.-W. Lee and K.-W. Park, Phys. Chem. Chem. Phys., 2011, 13, 12705-12707.

57 S. Wang, L. Zhang, C. Sun, Y. Shao, Y. Wu, J. Lv and X. Hao, Adv. Mater., 2016, 28, 3768-3776.

58 Z. Wang, Z. Li and Z. Zou, J. Power Sources, 2015, 296, 53-63. 59 A. L. Hector, Chem. Soc. Rev., 2007, 36, 1745-1753.

60 A. W. Jackson and A. L. Hector, J. Mater. Chem., 2007, 17, 1016.

61 A. W. Jackson, O. Shebanova, A. L. Hector and P. F. McMillan, J. Solid State Chem., 2006, 179, 1383-1393.

62 B. M. Gray, S. Hassan, A. L. Hector, A. Kalaji and B. Mazumder, Chem. Mater., 2009, 21, 4210-4215.

63 C. F. Mallinson, B. M. Gray, A. L. Hector, M. A. Mclachlan and J. R. Owen, Inorg. Chem., 2013, 9994-9999.

64 M. Zhang, N. Garcia-Araez, A. L. Hector and J. R. Owen, J. Mater. Chem. A, 2017, 5, 2251-2260.
65 Inorg. Cryst. Struct. Database (ICSD, Fiz Karlsruhe) accessed via EPSRC-funded Natl. Chem. Database Serv. hosted by R. Soc. Chem.

66 D. A. Shirley, Phys. Rev. B, 1972, 5, 4709-4714.

67 J. H. Scofield, J. Electron Spectrosc. Relat. Phenom., 1976, 8, 129-137.

68 G. Wang, H. Wang, X. Lu, Y. Ling, M. Yu, T. Zhai, Y. Tong and Y. Li, Adv. Mater., 2014, 26, 2676-2682.

69 L. Yin, R. T. David, R. K. Mike, L. M. Brian and M. L. Richard, J. Am. Ceram. Soc., 1997, 80, 705-716.

70 D. D. L. Chung, Carbon Fiber Composites, ButterworthHeinemann, Newton MA, 2012.

71 Z. H. Sheng, L. Shao, J. J. Chen, W. J. Bao, F. Bin Wang and X. H. Xia, ACS Nano, 2011, 5, 4350-4358.

72 A. Choudhury, J. H. Kim, S. Sinha Mahapatra, K. S. Yang and D. J. Yang, ACS Sustainable Chem. Eng., 2017, 5, 2109-2118. 73 Y. Xie and D. Wang, J. Alloys Compd., 2016, 665, 323-332.

74 J. Bae, M. K. Song, Y. J. Park, J. M. Kim, M. Liu and Z. L. Wang, Angew. Chem., Int. Ed., 2011, 50, 1683-1687.

75 X. Xiao, T. Li, P. Yang, Y. Gao, H. Jin, W. Ni, W. Zhan, X. Zhang, Y. Cao, J. Zhong, L. Gong, W.-C. Yen, W. Mai, J. Chen, K. Huo, Y.-L. Chueh, Z. L. Wang and J. Zhou, ACS Nano, 2012, 6, 9200-9206.

76 X. Xiao, X. Peng, H. Jin, T. Li, C. Zhang, B. Gao, B. Hu, K. Huo and J. Zhou, Adv. Mater., 2013, 25, 5091-5097.

77 P. Yang, X. Xiao, Y. Li, Y. Ding, P. Qiang, X. Tan, W. Mai, Z. Lin, W. Wu, T. Li, H. Jin, P. Liu, J. Zhou, C. P. Wong and Z. L. Wang, ACS Nano, 2013, 2617-2626.

78 P. Xu, T. Gu, Z. Cao, B. Wei, J. Yu, F. Li, J. H. Byun, W. Lu, Q. Li and T. W. Chou, Adv. Energy Mater., 2014, 4, 1-6. 